\title{
Overcoming Barriers to Collaboration in an Open Source Ecosystem
}

\author{
Derek Smith, Asrar Alshaikh, Rawan Bojan, Anish Kak, \\ and Mohammad Mehdi Gharaei Manesh
}

\author{
"Yes, we are all different. Different customs, different") \\ foods, different mannerisms, different languages, but not \\ so different that we cannot get along with one another. If \\ we will disagree without being disagreeable.
}

\author{
J. Martin Kohe \\ Author and Psychologist
}

\begin{abstract}
Leveraging open source practices provides value to businesses when entrepreneurs and managers understand how to collaborate effectively in an open source ecosystem. However, the complex mix of different actors and varying barriers to effective collaboration in the ecosystem pose a substantial challenge. How can a business create and capture value if it depends on effective collaboration among these different groups? In this article, we review the published research on open source collaboration and reveal insights that will be beneficial to entrepreneurs and managers. We organize the published research into four streams based upon the following actor groups: i) governance actors, ii) competitors, iii) complementors, and iv) the core community. Then, through induction and synthesis, we identify barriers to collaboration, first by ecosystem and then by actor group. Finally, we offer six recommendations for identifying and overcoming barriers to collaboration in an open source ecosystem.
\end{abstract}

\section{Introduction}

Collaboration is the act of working with another individual or grouping to create something. It involves working jointly and openly with others. When collaborators bring their own diverse skills and experience and new perspectives - the potential for innovation is great. However, collaboration is far from easy, and the diversity that brings benefits to the experience can also present barriers to collaboration. In an open source ecosystem, where collaboration is essential and the diversity of contributors is often high, these barriers can be substantial.

Open source collaboration is the act of working with different group of actors on a project to produce and create open source software (Nan and Kumar, 2013; tinyurl.com/k5a8yt3). For companies that wish to leverage open source software as part of their business models, effective collaboration is essential. However, the open environment introduces business- and people-related issues that can restrict or prevent open collaboration among the different groups of actors. Entrepreneurs and managers are faced with questions such as: How open should an actor be with sensitive or confidential business information, and with whom can it safely be shared? How can we collaborate openly with a competitor? How do we collaborate with actors from around the world, where cultural differences may affect our interactions? These business- and people- related issues inherent in an open source ecosystem create barriers to effective collaboration if entrepreneurs and managers fail to understand and overcome the barriers.

In this article, we examine the barriers to effective collaboration in an open source ecosystem, and we ask whether the different groups of actors in such an ecosystem face the same or different barriers. To success- 


\title{
Overcoming Barriers to Collaboration in an Open Source Ecosystem
}

\author{
Derek Smith, Asrar Alshaikh, Rawan Bojan, Anish Kak, and Mohammad Mehdi Gharaei Manesh
}

fully collaborate in an open source ecosystem, entrepreneurs and managers must understand: i) the degree of similarity or dissimilarity between barriers to collaboration in such an ecosystem and ii) how the barriers relate to the different groups of actors.

In the existing literature, previous research has focused on specific actors in open source ecosystems, such as: foundations, communities, governments, complementors, competitors, leaders, developers, adapters, users, and expert users. However, there is a lack of research from the broader perspective of the collaboration barriers that may arise within and between these various groups of actors. To achieve business success through leveraging an open source ecosystem, entrepreneurs and managers need to:

1. Identify and understand barriers to collaboration common to all groups of actors in an open source ecosystem

2. Identify and understand barriers to collaboration unique to specific groups of actors in an open source ecosystem

3. Overcome all these barriers for overall effective collaboration in an open source ecosystem

In this article, we make five contributions. First, we identify barriers to collaboration common to all groups of actors in an open source ecosystem. Second, we categorize actors in an open source ecosystem into four different groups. Third, we identify open source collaboration barriers unique to the different groups. Fourth, we assemble the research articles relevant to the topic of collaboration in open source ecosystems into four streams based upon our four different groups of actors. Finally, we provide recommendations to entrepreneurs and managers to identify and overcome barriers to collaboration from a different group of actor perspective.

The article is organized into four sections. The first section summarizes the results of our literature review concerning open source collaboration. The second section provides a definition of open source collaboration as it relates to open source business and an open source ecosystem. This section also identifies open source collaboration barriers common in the ecosystem and unique to the four different groups of actors. The third section provides recommendations for entrepreneurs and managers to overcome collaboration barriers in an open source ecosystem. A final section concludes the article.

\section{Literature Review}

Table 1 summarizes the 15 papers we reviewed following a search of literature relating to open source collaboration. Based on patterns we observed, we organized the literature into four streams based on the relevance to four groups of actors in an open source ecosystem: i) governance actors, ii) competitors, iii) complementors, and iv) the core community. Organizing the literature in this way revealed insights into the common barriers in an open source ecosystem and the barriers that are unique to each group of actor.

\section{Governance actors}

Five of the articles we reviewed in Table 1 relate collaboration with governance actors. Lack of governance can be an overall barrier (Muegge, 2011; timreview.ca/ article/495), but one of the main barriers is the disparate interests or divergent interests between actors in the ecosystem (O'Mahony and Bechky, 2008; tinyurl.com/ lothrqs). Other relevant barriers include the lack of vision and standards relating to the joint efforts in the ecosystem (Kshetri and Schiopu, 2007; tinyurl.com/n740eem; Skerrett, 2009; timreview.ca/article/219). A lack of openness and transparency (Smith and Milinkovich, 2007; timreview.ca/article/94) can also be a barrier that restricts collaboration in an open source ecosystem. Governance actors manage different interests, solidify and converge interests, and overall reduce business differences between actors in an open source ecosystem (O'Mahony and Bechky, 2008; tinyurl.com/lothrqs). Openness and transparency (Skerrett, 2009; timreview.ca/article/219) are also required for access to shared resources and gaining commitment from the actors (Smith and Milinkovich, 2007; timreview.ca/article/94). Collaboration with governance actors is a process of compromise to establish an ecosystem structure that enables business activities (O'Mahony and Bechky, 2008; tinyurl.com/ lothrqs). A vision and standards are required for international collaboration (Kshetri and Schiopu, 2008; tinyurl.com/n740eem); they enable the actors in an open source ecosystem to create value and collaborate.

\section{Competitors}

Three articles summarized in Table 1 relate to open source collaboration with competitors. Barriers to overcome when collaborating with competitors include a lack of trust, the need to identify shared objectives, and the need to share access to resources in contrast to a closed approach where a company looks to assimilate key resources into its business (Shamsuzzoha et al., 2013; tinyurl.com/nnvmcr2). Other barriers include concerns related to releasing confidential information 


\section{Overcoming Barriers to Collaboration in an Open Source Ecosystem Derek Smith, Asrar Alshaikh, Rawan Bojan, Anish Kak, and Mohammad Mehdi Gharaei Manesh}

Table 1. A summary of open source collaboration literature relevant to open source ecosystems

\begin{tabular}{|c|c|c|c|c|}
\hline Stream & Author (Year) & Source & Open Source Actor(s) & Focus \\
\hline \multirow[t]{5}{*}{$\begin{array}{l}\text { Governance } \\
\text { Actors }\end{array}$} & $\begin{array}{l}\text { Muegge (2011) } \\
\text { timreview.ca/article/495 }\end{array}$ & $\begin{array}{l}\text { Technology } \\
\text { Innovation } \\
\text { Management } \\
\text { Review } \\
\text { (TIM Review) }\end{array}$ & $\begin{array}{l}\text { Community } \\
\text { members, developer, } \\
\text { foundation, users, } \\
\text { and adopters }\end{array}$ & $\begin{array}{l}\text { A systems perspective on communities, institutions, } \\
\text { companies, and individuals }\end{array}$ \\
\hline & $\begin{array}{l}\text { Smith \& Milinkovich (2007) } \\
\text { timreview.ca/article/94 }\end{array}$ & TIM Review & Foundation & $\begin{array}{l}\text { Openness, transparency, and meritocracy with } \\
\text { resources and commitment; ability of the ecosystem to } \\
\text { create value }\end{array}$ \\
\hline & $\begin{array}{l}\text { O'Mahony \& Bechky (2008) } \\
\text { tinyurl.com/lothrqs }\end{array}$ & $\begin{array}{l}\text { Administrative } \\
\text { Science Quarterly }\end{array}$ & $\begin{array}{l}\text { Foundation } \\
\text { (boundary } \\
\text { organizations) }\end{array}$ & $\begin{array}{l}\text { Managing the boundaries of collaboration where } \\
\text { disparate and convergent interests of different actors } \\
\text { are present. Recommendations include the need to } \\
\text { identify critical differences and establish a governance } \\
\text { structure, membership, ownership, and control over } \\
\text { the project for enabling collaboration. }\end{array}$ \\
\hline & $\begin{array}{l}\text { Kshetri \& Schiopu (2007) } \\
\text { tinyurl.com/n74oeem }\end{array}$ & $\begin{array}{l}\text { Journal of Asia- } \\
\text { Pacific Business }\end{array}$ & $\begin{array}{l}\text { Foundation } \\
\text { (government) }\end{array}$ & $\begin{array}{l}\text { Effective international collaborations requirements, } \\
\text { including a vision and influence on a technology } \\
\text { trajectory, setting standards, and promotion }\end{array}$ \\
\hline & $\begin{array}{l}\text { Skerrett (2009) } \\
\text { timreview.ca/article/219 }\end{array}$ & TIM Review & Foundation & $\begin{array}{l}\text { Collaborative software development with competitors } \\
\text { in a foundation governed open source community }\end{array}$ \\
\hline \multirow[t]{4}{*}{ Competitors } & $\begin{array}{l}\text { Lindman \& Rajala (2012) } \\
\text { timreview.ca/article/510 }\end{array}$ & TIM Review & Competitor & $\begin{array}{l}\text { Focus interactions with the user to gain user } \\
\text { involvement. Ensure access to important external } \\
\text { resources rather than assimilate or build new internal } \\
\text { resources. Take advantage of open innovation process } \\
\text { but think about the purpose of external contributions. } \\
\text { Make the goal of collaboration clear so that it becomes } \\
\text { easier to collaborate and reveal confidential } \\
\text { information where it makes business sense. }\end{array}$ \\
\hline & $\begin{array}{l}\text { Schreuders et al. (2011) } \\
\text { timreview.ca/article/413 }\end{array}$ & TIM Review & Competitor & $\begin{array}{l}\text { Hybrid business model based upon an open source } \\
\text { licensing model, which allows different users different } \\
\text { access and collaboration based upon the selected open } \\
\text { source licensing model. The hybrid business model } \\
\text { removes restrictions and attracts actors to the open } \\
\text { source community, building a resource to test and } \\
\text { validate products. }\end{array}$ \\
\hline & $\begin{array}{l}\text { Shamsuzzoha et al. (2013) } \\
\text { tinyurl.com/nnvmcr2 }\end{array}$ & $\begin{array}{l}\text { International } \\
\text { Journal of } \\
\text { Computer } \\
\text { Integrated } \\
\text { Manufacturing }\end{array}$ & Competitor & $\begin{array}{l}\text { Building trust and overcoming fears relating to } \\
\text { confidentiality and the exchange of information } \\
\text { between competitors. This requires common objectives } \\
\text { and rules/procedures for exchanging information and } \\
\text { foundations for cooperation. Individual objectives must } \\
\text { be clear and aligned to the shared objectives }\end{array}$ \\
\hline & $\begin{array}{l}\text { Muegge (2013) } \\
\text { timreview.ca/article/655 }\end{array}$ & TIM Review & $\begin{array}{l}\text { Complementors, } \\
\text { suppliers, customers, } \\
\text { competitors, } \\
\text { developers, and users }\end{array}$ & $\begin{array}{l}\text { Identifies the actors in the open source ecosystem such } \\
\text { as customers, suppliers, competitors, and many other } \\
\text { stakeholders. }\end{array}$ \\
\hline
\end{tabular}

Continued... 


\section{Overcoming Barriers to Collaboration in an Open Source Ecosystem Derek Smith, Asrar Alshaikh, Rawan Bojan, Anish Kak, and Mohammad Mehdi Gharaei Manesh}

\section{Table 1 (continued). A summary of open source collaboration literature relevant to open source ecosystems}

\begin{tabular}{lllll}
\hline Stream & Author (Year) & Source & Open Source Actor(s) & Focus \\
\hline Complementors & $\begin{array}{l}\text { Skerrett (2011) } \\
\text { timreview.ca/article/409 }\end{array}$ & TIM Review & $\begin{array}{l}\text { Multi-vendor, } \\
\text { complementors, } \\
\text { users, adopters, and } \\
\text { contributors }\end{array}$ & $\begin{array}{l}\text { License strategy is important to engage a larger portion } \\
\text { of community. A copyleft license will generate a wider } \\
\text { collaboration. License strategy can also earn trust and } \\
\text { gain access to a larger portion of community. Use a } \\
\text { vendor-neutral governance structure. }\end{array}$ \\
\cline { 2 - 5 }
\end{tabular}

\begin{tabular}{|c|c|c|c|}
\hline $\begin{array}{l}\text { Muegge (2013) } \\
\text { timreview.ca/article/655 }\end{array}$ & TIM Review & $\begin{array}{l}\text { Complementors, } \\
\text { suppliers, customers, } \\
\text { competitors, } \\
\text { developers, and users }\end{array}$ & $\begin{array}{l}\text { Identifies the actors in the open source ecosystem such } \\
\text { as customers, suppliers, competitors, and many other } \\
\text { stakeholders. }\end{array}$ \\
\hline
\end{tabular}

\begin{tabular}{|c|c|c|c|c|}
\hline \multirow[t]{2}{*}{ Core Community } & $\begin{array}{l}\text { Muegge (2011) } \\
\text { timreview.ca/article/495 }\end{array}$ & TIM Review & $\begin{array}{l}\text { Community } \\
\text { members, developer, } \\
\text { foundation, users, } \\
\text { and adopters }\end{array}$ & $\begin{array}{l}\text { A systems perspective on the community, institutions, } \\
\text { companies, and individuals. Shared governance and } \\
\text { participation are important to collaboration in an open } \\
\text { source community. }\end{array}$ \\
\hline & $\begin{array}{l}\text { Evans \& Wolf (2005) } \\
\text { tinyurl.com/l9dgpea }\end{array}$ & $\begin{array}{l}\text { Harvard Business } \\
\text { Review }\end{array}$ & $\begin{array}{l}\text { Community } \\
\text { members, leaders, } \\
\text { and competitors }\end{array}$ & $\begin{array}{l}\text { Members belong to different organizations with no } \\
\text { defined role or responsibility; a mix of amateurs and } \\
\text { professionals with different skills. Competitors } \\
\text { collaborate: must think about options and adaptability } \\
\text { not integration and static efficiency. Build trust in the } \\
\text { community and collaborate freely and productively. } \\
\text { Leaders are valuable; they instruct community } \\
\text { members, articulate clear goals, and connect people. } \\
\text { Trust is currency and reputation is power. }\end{array}$ \\
\hline
\end{tabular}

\begin{tabular}{|c|c|c|c|}
\hline $\begin{array}{l}\text { Skerrett (2011) } \\
\text { timreview.ca/article/409 }\end{array}$ & TIM Review & $\begin{array}{l}\text { Multi-vendor, } \\
\text { complementors, } \\
\text { users, adopters, and } \\
\text { contributors }\end{array}$ & $\begin{array}{l}\text { License strategy is important to engage a larger portion } \\
\text { of community. A copyleft license will generate a wider } \\
\text { collaboration. License strategy can also earn trust and } \\
\text { gain access to larger portion of community. Use a } \\
\text { vendor-neutral governance structure. }\end{array}$ \\
\hline
\end{tabular}

Sarker et al. (2009) IEEE Transactions Leaders Leadership in the community. Leaders are not

$\begin{array}{lll}\text { tinyurl.com/132zjuf } & \text { on Professional } & \text { reassigned; rather, they emerge from the project and }\end{array}$
Communication are required for effective collaboration. Information systems development ability, greater contributions are identified with leadership.

$\begin{array}{ll}\text { Nan \& Kumar (2013) } & \text { IEEE Transactions } \\ \text { tinyurl.com } / \mathrm{k} 5 \mathrm{a} 8 \mathrm{yt} 3 & \text { on Engineering } \\ & \text { Management }\end{array}$

Size and format of a team of developers in association with the level of structural interdependency are key for effective collaboration. Positive impact on a project with a high level of structural interdependency may be achieved with centralized teams of developers and larger teams. Smaller teams required for positive impact on projects with a low level of structural interdependency; centralized teams can impact project performance on such projects.

\begin{tabular}{llll}
\hline $\begin{array}{l}\text { Colazo (2010) } \\
\text { tinyurl.com/mwuovbm }\end{array}$ & $\begin{array}{l}\text { International } \\
\text { Jounal of } \\
\text { Innovation } \\
\text { Management }\end{array}$ & Developers & $\begin{array}{l}\text { Developer density is negatively associated with quality } \\
\text { and positively associated with productivity. } \\
\text { Centralization is positively associated with both quality } \\
\text { and productivity. Collaborating beyond boundaries is } \\
\text { positively associated with quality but negatively } \\
\text { associated with productivity. }\end{array}$ \\
\hline $\begin{array}{l}\text { Hemetsberger \& Reinhardt } \\
\text { (2009) tinyurl.com/qz3mszp }\end{array}$ & $\begin{array}{l}\text { Organization } \\
\text { Studies }\end{array}$ & Expert Users & $\begin{array}{l}\text { Coat tailing is the pursuit of individual and collective } \\
\text { needs; it requires achieving the best balance between } \\
\text { individual and collective needs. }\end{array}$ \\
\hline $\begin{array}{l}\text { Muegge (2013) } \\
\text { timreview.ca/article/655 }\end{array}$ & TIM Review & $\begin{array}{l}\text { Complementors, } \\
\text { suppliers, customers, } \\
\text { competitors, } \\
\text { developers, and users }\end{array}$ & $\begin{array}{l}\text { Identifies the actors in the open source ecosystem such } \\
\text { as customers, suppliers, competitors, and many other } \\
\text { stakeholders. }\end{array}$ \\
\hline
\end{tabular}




\title{
Overcoming Barriers to Collaboration in an Open Source Ecosystem
}

\author{
Derek Smith, Asrar Alshaikh, Rawan Bojan, Anish Kak, and Mohammad Mehdi Gharaei Manesh
}

(Lindman and Rajala, 2012; timreview.ca/article/510); removing restrictions that prevent open collaboration with competitors (Schreaders et al., 2011; timreview.ca/ article/413); and the need to attract and build a larger community of competitors that may be leveraged (Schreuders et al., 2011; timreview.ca/article/413).

\section{Complementors}

Two articles summarized in Table 1 relate to collaboration with complementors. Barriers include intellectual property in the form of a right that prevents use and collaboration as well as an inability to share confidential information, lack of trust, moving from closed to open, vendor dominance, and trust (Skerrett, 2011; timreview .ca/article/409) and lack of transparency (Muegge, 2013; timreview.ca/article/655).

\section{Core Community}

Eight articles summarized in Table 1 relate to collaboration with the core community (i.e., users, adopters, contributors, leaders, developers and expert users). Barriers to overcome when collaborating with the core community include:

- a lack of leadership; leaders are not appointed but evolve out of the community, and there may be cultural differences in leadership (Sarker et al., 2009; tinyurl.com/l32zjuf). Collaboration with the core community requires identification of a leader or leaders of the project to ensure productivity and balance the needs of the actors in the core community

- the size and format of the community, which affects collaboration as well as the degree of centralization or decentralization (Nan and Kumar, 2013; tinyurl.com/ k5a8yt3). Going beyond boundaries can be a barrier to productivity (Colazo, 2010; tinyurl.com/mwuovbm)

- the individual needs of expert users, which may not align with the needs of the community (Hemetsberger and Reinhardt, 2009; tinyurl.com/qz3mszp)

- the mix of developer attributes, such as the amount of skill or a lack of skill. In addition, a developer's role and responsibilities, which tend to be undefined in an open source ecosystem, (Evans and Wolf, 2005; tinyurl.com/19dgpea) also create barriers to effective collaboration.

\section{Open Source Barriers to Collaboration}

Open source business shifts "the focus from the production value to the use value of the software artifact and emphasizes services and meta-services surrounding the artifact" (Feller et al., 2006; tinyurl.com/34eppr5). The open source ecosystem includes a number of different actors involved in the artifact and the services to provide a complete solution to customers. The ecosystem has little organization and order. The ecosystem may further include a platform where actors interact to create products or offer services. The platform offers value to the actors in the ecosystem but the platform also brings together many different technology, people and business relates issues (Kilamo et al., 2012; tinyurl.com/ n5gnrgu). The actors are motivated by common interests or business models (Manikas and Hansen, 2013; tinyurl.com/lsrljj5). Common interests include a motivation to join the ecosystem where there is overlap in business and the actors work collectively towards a common task, asset, or resource. A business model is also a motivation where the business model in part relies on a nondifferentiating common task, asset, or resource.

As we identified earlier, the collection of actors includes four main groups: i) governance actors, ii) competitors, iii) complementors, and iv) the core community. Governance actors are important and manage the boundaries of collaboration (O'Mahony and Bechky, 2008; tinyurl.com/lothrqs), which are essential to the operation of an open source ecosystem. The type of governance actor varies with the open source ecosystem and may include a foundation (O'Mahony and Bechky, 2008; tinyurl.com/lothrqs; Skerrett, 2009; timreview.ca/article/219; Smith and Milinkovich, 2007; timreview.ca/article/94), a federal government (Kshetri and Schiopu, 2007; tinyurl .com/nnvmcr2), or the community (O'Mahony and Bechky, 2008; tinyurl.com/lothrqs). The core community comprises the actors in the open source ecosystem that work on the open source project to develop and test the product (Kilamo et al., 2012; tinyurl.com/n5gnrgu). Actors in the core community include: leaders (Sarker et al., 2009; tinyurl.com/l32zjuf), developers (Nan and Kumar, 2013; tinyurl.com/k5a8yt3; Colazo, 2010; tinyurl.com/ mwuovbm), users (Muegge, 2013; timreview.ca/article/655), adopters (Skerrett, 2011; timreview.ca/article/409; Muegge, 2011; timreview.ca/article/495) and expert users (Hemetsberger and Reinhardt, 2009; tinyurl.com/qz3mszp). Leaders provide overall leadership to the development portion of the community. Developers work on the open source project creating and testing the software. Users are important for providing requirements. Adopters are key to using the open source project. Expert users provide insight into the project for both present and future needs.

Governance actors resolve differences in the community to ensure the health of the ecosystem (Smith 


\title{
Overcoming Barriers to Collaboration in an Open Source Ecosystem
}

\author{
Derek Smith, Asrar Alshaikh, Rawan Bojan, Anish Kak, and Mohammad Mehdi Gharaei Manesh
}

and Milinkovich, 2007; timreview.ca/article/94). Resolving differences involves collaboration with all other groups. Competitors create and share value while collaborating with the core community, complementors, and other competitors. Complementors help build a larger community that can be leveraged to create and share value (Skerrett, 2011; timreview.ca/article/409); they collaborate with the core community as well as competitors and other complementors. The core community includes actors such as leaders, developers, and expert users and the associated collaboration barriers are different within the core community.

Table 2 is a summary of collaboration barriers from the literature pertaining to these four main groups, including the different types of actors within each group. The barriers in this table were identified through a close reading of the articles in the literature review. For example, the barrier relating to lack of project representation, which applies to governance actors, is derived from O'Mahony and Bechky (2008; tinyurl.com/lothrqs): "Though project members were not eager to impose a 'command and control structure onto the community', this desire for 'republics' led the projects to adapt a governance structure that established project representation and preserved pluralistic control." Similarly, the governance-actor barrier relating to challenges in defining the scope of collaboration is derived from Skerrett (2009; timreview.ca/article/219): "Determining the scope of collaboration is often the most challenging aspect of starting an open source project. The key challenge is to understand which areas of technology are core and which are non-core to the business value of that organization." Another example is the inequality barrier faced by complementors, which was derived from (Skerrett, 2011; timreview.ca/article/409): "For singlevendor-dominated communities, copyright assignment was required to allow the receiving vendor the ability to create revenue streams by implementing a dual license for the project code. MySQL is the most common example of this strategy. Unfortunately, this approach creates a revenue stream that is unique to one company. In turn, this inequality creates a barrier to involvement by other companies."

These examples show how the collaboration barriers listed in Table 2 were identified from the literature. Table 3 is a synthesis of the barriers from Table 2 to reveal which barriers are common across the groups and which barriers are unique to each group.
There are four barriers to collaboration that are common to all groups in an open source ecosystem: i) intellectual property, ii) moving from closed to open, iii) openness, and iv) a lack of transparency. The literature shows that trust is important to most groups in the ecosystem with the exception of the governance actors. A particular challenge for competitors and the core community is the diverse mix of people, and the potential for undefined roles and responsibilities. A particular challenge for complementors and the core community is inequality in the ecosystem. The governance actors and the core community tend to have a broad range of different barriers to collaboration.

\section{Recommendations for Entrepreneurs and Managers}

We offer six recommendations for entrepreneurs and managers seeking to overcome collaboration barriers for successful collaboration in an open source ecosystem.

\section{Identify the common and unique barriers to collabora- tion in your open source ecosystem}

The barriers to collaboration in an open source ecosystem include barriers common to all groups of actors in the ecosystem and barriers unique to specific groups of actors. Entrepreneurs and managers need to seek out, understand, and pay attention to these very different barriers for successful collaboration in an open source ecosystem. The specific nature of a given barrier will depend on the unique circumstances of your ecosystem, but Table 3 can help you systematically identify the types of common and unique barriers to collaboration.

\section{Strike a balance between open and closed}

Intellectual property that is not differentiating to a business should be released into the open. This requires early and ongoing identification of assets and information that may be open to the ecosystem and other assets and information that should be kept confidential. This includes patents, copyrights, designs and potential inventions. Trademarks and know-how become more valuable and strategic to open source business.

Move quickly and make informed business decisions in the open environment of the ecosystem and be open and transparent with competitors based upon your business decisions when collaborating with any group of actors in an open source ecosystem. 


\title{
Overcoming Barriers to Collaboration in an Open Source Ecosystem
}

\author{
Derek Smith, Asrar Alshaikh, Rawan Bojan, Anish Kak, and Mohammad Mehdi Gharaei Manesh
}

\section{Seek representation and effective governance}

Understand the collaboration barriers that relate to representation, pluralistic control, economic balance, disparate and divergent interests, ability to cooperate, vision, and standards. Then, ensure your business has a fair share of representation and become proactive with pluralistic control. Identify different interests early and compromise when collaborating with other groups of actors. Setting a clear vision and standards will assist you with effective collaboration with the governance group of actors.

\section{Collaborate effectively with the core community}

Understand the barriers with the core community that relate to equality, leadership, team structures, cultural differences, and new member integration. Be fair and equitable with the core community. Attempt to identify the leader, or assist developing a leader in the community. Ensure you have an appropriate team structures to assist collaboration with the core community and pay attention to cultural differences associated with a global community, and assist with integrating new members into the community.

\section{Compete and collaborate with competitors}

Understand the collaboration barriers with competitors that relate to objectives, roles, responsibilities, and shared values. In advance of engaging competitors in the open source ecosystem, ensure you have clear objectives and defined roles, responsibilities, and values. Make a point of understanding your competitor's objectives, roles, responsibilities, and values. Ensure or negotiate an appropriate understanding of joint roles, responsibilities, and values for collaborating in the open source ecosystem.

\section{Recognize the challenges of diversity}

Be aware of the diversity in the competitor and core community groups; it can be beneficial, but it also introduces collaboration challenges. Diversity includes different levels of knowledge or education and different levels of skills. There may be actors from many different parts of the world, which creates the potential for cultural barriers to collaboration.

\section{Conclusion}

There are many barriers to collaboration in an open source ecosystem. Some of these barriers are common to all actors in the ecosystem, but others are unique to specific groups of actors in the ecosystem. Barriers common to all groups are: intellectual property, businessand people-related issues when moving from a closed system to an open system, understanding where and how to be open in business with other actors in the ecosystem including competitors, and a potential lack of transparency that can impact success. Effective collaboration requires an open approach to all groups in the ecosystem based upon informed business decisions and an understanding of the barriers in an open source ecosystem. Effective collaboration requires that entrepreneurs and managers identify and understand the collaboration barriers both common and unique to each of the four groups of actors in the ecosystem and then overcome these barriers. 


\section{Overcoming Barriers to Collaboration in an Open Source Ecosystem}

\section{Derek Smith, Asrar Alshaikh, Rawan Bojan, Anish Kak, and Mohammad Mehdi Gharaei Manesh}

Table 2. Open source ecosystem actors, sub-groups, and collaboration barriers

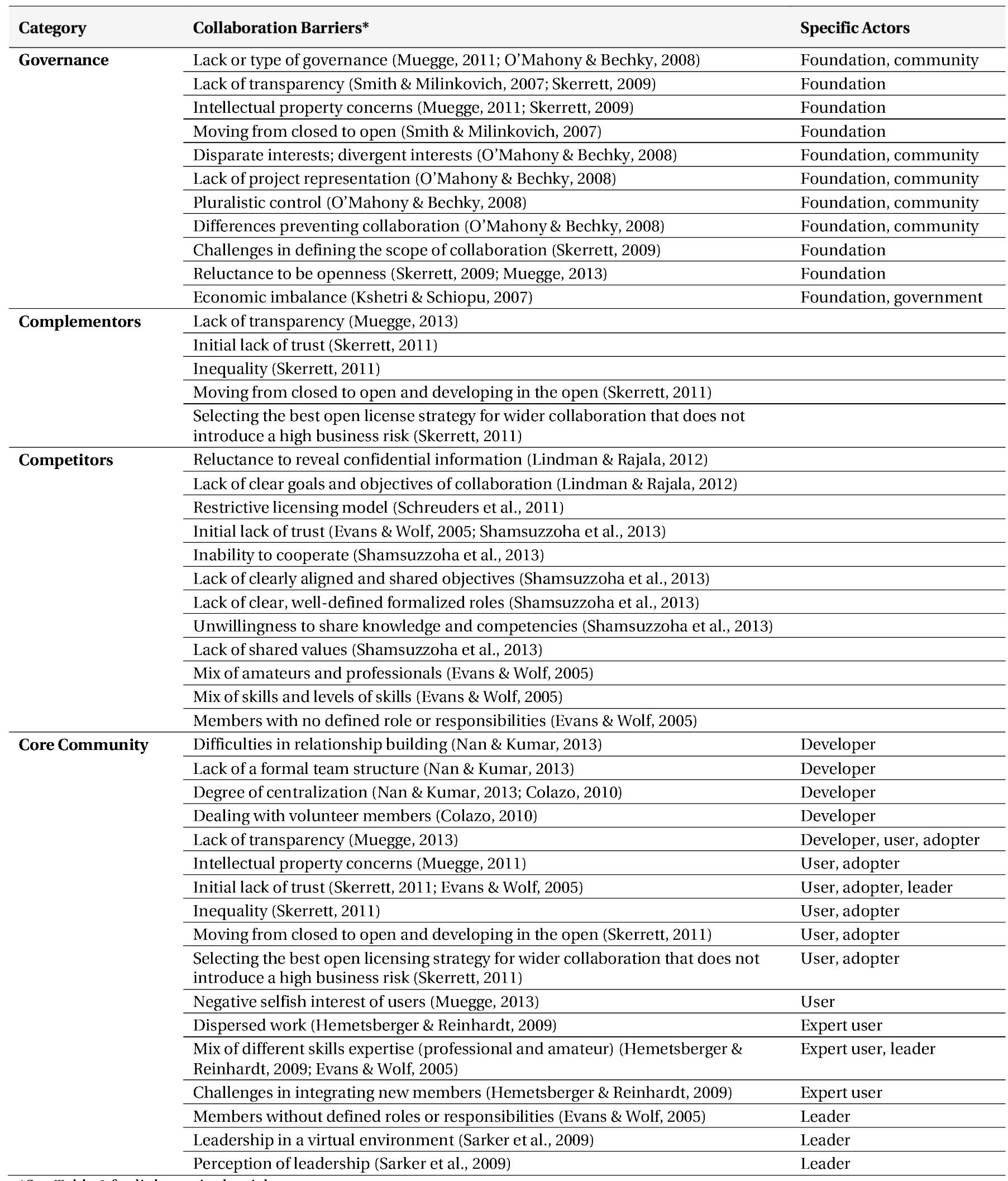

\footnotetext{
*See Table 1 for links to cited articles.
} 


\section{Overcoming Barriers to Collaboration in an Open Source Ecosystem Derek Smith, Asrar Alshaikh, Rawan Bojan, Anish Kak, and Mohammad Mehdi Gharaei Manesh}

Table 3. Barriers to collaboration in an open source ecosystem, by actor group

\begin{tabular}{|c|c|c|c|c|}
\hline \multirow[b]{2}{*}{ Potential Barriers to Collaboration } & \multicolumn{4}{|c|}{ Actor Group } \\
\hline & Governance & Complementors & Competitors & Community \\
\hline Intellectual property concerns & $\checkmark$ & $\checkmark$ & $\checkmark$ & $\checkmark$ \\
\hline $\begin{array}{l}\text { Moving from closed to open and sharing information and } \\
\text { knowledge with everyone in the ecosystem }\end{array}$ & $\checkmark$ & $\checkmark$ & $\checkmark$ & $\checkmark$ \\
\hline Reluctance to be open & $\checkmark$ & $\checkmark$ & $\checkmark$ & $\checkmark$ \\
\hline Lack of transparency & $\checkmark$ & $\checkmark$ & $\checkmark$ & $\checkmark$ \\
\hline Lack of trust & & $\checkmark$ & $\checkmark$ & $\checkmark$ \\
\hline $\begin{array}{l}\text { Challenges of interacting with a diversity of people with different } \\
\text { knowledge and experience }\end{array}$ & & & $\checkmark$ & $\checkmark$ \\
\hline Lack of clearly defined roles/responsibilities & & & $\checkmark$ & $\checkmark$ \\
\hline Inequality & & $\checkmark$ & & $\checkmark$ \\
\hline The business' lack of representation in the ecosystem & $\checkmark$ & & & \\
\hline Pluralistic control & $\checkmark$ & & & \\
\hline Economic imbalance between actors of different size & $\checkmark$ & & & \\
\hline Disparate/divergent interests & $\checkmark$ & & & \\
\hline Inability to cooperate & $\checkmark$ & & & \\
\hline Lack of vision/standards & $\checkmark$ & & & \\
\hline Lack of clear objectives & & & $\checkmark$ & \\
\hline Lack of shared values & & & $\checkmark$ & \\
\hline Lack of leadership & & & & $\checkmark$ \\
\hline $\begin{array}{l}\text { Lack of a format team structure to achieve a project objectives } \\
\text { (size/format/degree of centralization or decentralization) }\end{array}$ & & & & $\checkmark$ \\
\hline Cultural differences & & & & $\checkmark$ \\
\hline $\begin{array}{l}\text { Challenges with integrating new members into the ecosystem, } \\
\text { team, or project }\end{array}$ & & & & $\checkmark$ \\
\hline
\end{tabular}




\section{Overcoming Barriers to Collaboration in an Open Source Ecosystem}

\section{Derek Smith, Asrar Alshaikh, Rawan Bojan, Anish Kak, and Mohammad Mehdi Gharaei Manesh}

\section{About the Authors}

Derek Smith is the founder and principal of Magneto Innovention Management, an intellectual property consulting firm that assists entrepreneurs and small businesses with difficult intellectual property issues. He has over 20 years of experience working as an intellectual property management consultant and patent agent for IBM Canada, Bell Canada and, most recently, Husky Injection Molding Systems where he was Director, Global Intellectual Property. Prior to entering the field of intellectual property, he was an advisory engineer at IBM Canada where he was involved in a variety of leading-edge software development projects. Derek is currently a graduate student in the Technology Innovation Management (TIM) program at Carleton University in Ottawa, Canada. He also holds a BEng degree in Systems and Computer Engineering from Carleton University and is a registered patent agent in both Canada and the United States.

Asrar Abdulqader Alshaikh is a graduate student in the Technology Innovation Management (TIM) program at Carleton University in Ottawa, Canada. She holds a Bachelor of Accounting degree from King Abdulaziz University in Jeddah, Saudi Arabia. Her work experience includes customer service in a sale for distribution and communication company as well as working for the Alahli Bank (NCB) in Jeddah, Saudi Arabia. Her main area of research interest is collaborative consumption.

Rawan Mohammad Bojan is a graduate student in the Technology Innovation Management (TIM) program at Carleton University in Ottawa, Canada. She has professional experience in the banking industry and holds a Bachelor of Science in Accounting from King Abdulaziz University in Jeddah, Saudi Arabia.
Anish Kak is a graduate student in the Technology Innovation Management (TIM) program at Carleton University in Ottawa, Canada. He holds a BEng degree in Computer Science Engineering, from Birla Institute of Technology in India. Anish has two years of experience in the information technology services sector, which he gained while working for HewlettPackard in India. His research interests include the electronic sports ecosystem.

Mohammad Mehdi Gharaei Manesh is a graduate student in the Technology Innovation Management (TIM) program at Carleton University in Ottawa, Canada. He holds an MBA degree from Carleton University's Sprott School of Business and also has a degree in Biomedical Engineering from Tehran Polytechnic University in Iran. He has 5 years of working experience in a medical equipment company and his main area of interest relates to crowdsourcing and international business.

Citation: Smith, D., A. Alshaikh, R. Bojan, A. Kak, and M. M. G. Manesh. 2014. Overcoming Barriers to Collaboration in an Open Source Ecosystem. Technology Innovation Management Review. January 2014: 18-27.

Keywords: business ecosystem, open source, communities, governance, core community, competitors, complementors, collaboration, collaboration barriers 